\title{
Tapanuli orangutan endangered by Sumatran hydropower scheme
}

The Tapanuli orangutan survives today in less than $1,200 \mathrm{~km}^{2}$ of rainforest in northern Sumatra, Indonesia, in an area known as Batang Toru, where it was scientifically discovered ${ }^{1}$ in 1997. Teeming with endangered fauna and flora, the Batang Toru forest has been partially felled and fragmented and parts of the remainder allocated to agriculture, mining, hydropower and geothermal-energy production. The Tapanuli orangutan is estimated to number just 767 individuals, divided among three subpopulations ${ }^{1}$. Its total remaining habitat is merely a tenth the size of Sydney, Australia.

The most imminent threat to the Tapanuli orangutan is a $\$ 1.6$ billion hydropower and road-building scheme that will cut across its largest subpopulation (see figure 1). The scheme's main corporate proponent is North Sumatera Hydro Energy, a Jakarta-based firm, but it is being implemented by Sinohydro, China's national hydropower agency and the largest dam-builder in the world ${ }^{2}$.

International funders are increasingly leery of the dam project. The World Bank's International Finance Corporation concluded that the project was too risky given its potentially severe impacts on imperilled fauna and flora ${ }^{3}$. It also confirmed that the dam and road infrastructure would slice through the only area of intact forest that still links the ape's three subpopulations - critical findings that are being downplayed by the project's proponents $^{3,4}$. For similar reasons, the Bank of China and Asian Development Bank have also declined to support the project ${ }^{3}$.
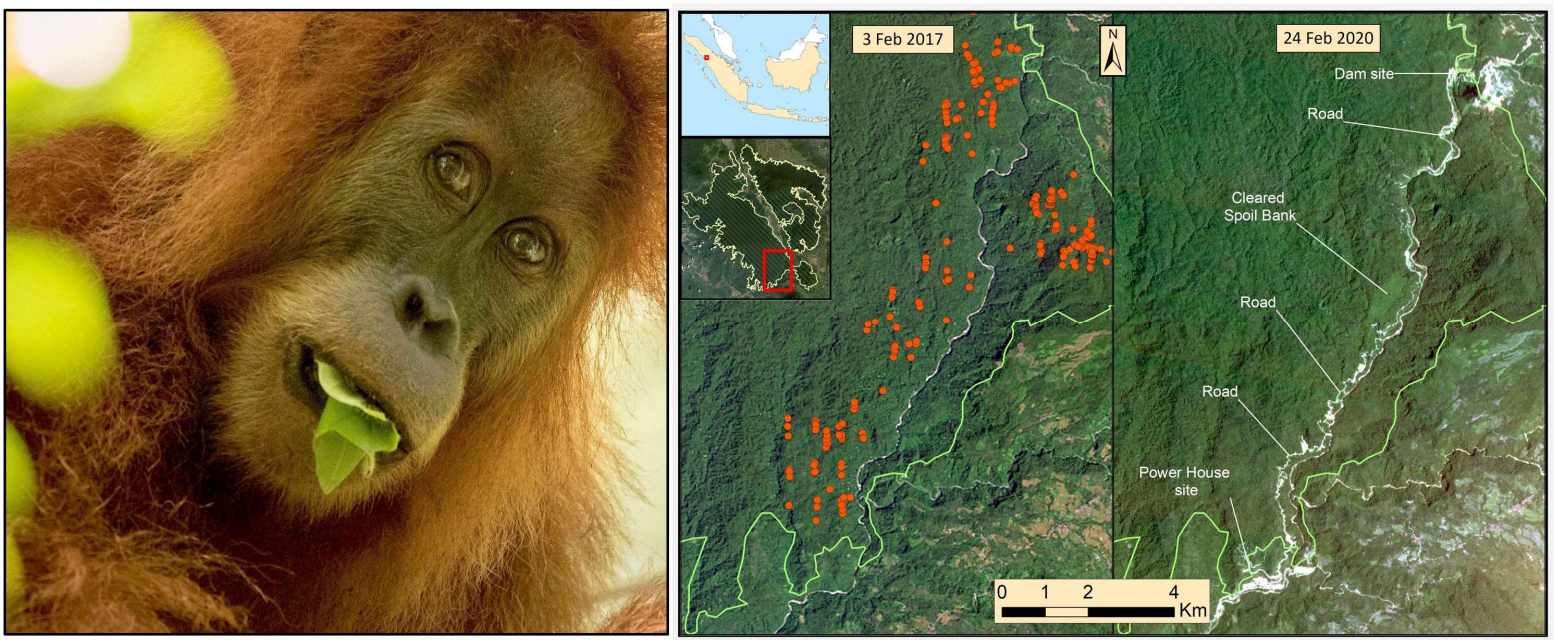

Figure 1. The Tapanuli orangutan and the hydrodam that imperils it in Sumatra, Indonesia. Orange dots show where Tapanuli orangutans or their nests were tallied before construction began, while the right panel shows current dam, earthworks, road and powerline construction and associated deforestation.

Despite strident reservations from scientists, conservationists, and many observers, the hydropower scheme at Batang Toru is charging ahead ${ }^{5}$. For instance, the project proponents claim that Tapanuli orangutans are now less abundant in the dam-project area than formerly documented ${ }^{6}$, but this is because the apes flee major disturbances like heavy earthworks and road building 5 . The proponents also fail to acknowledge that extensive roadbuilding associated with the dam project will lead to elevated deforestation, logging and poaching that imperil the endangered ape $\mathrm{e}^{5,7}$. 
The project's proponents are also doing their best to suppress opposition to their project $^{8}$. For instance, PanEco, a Swiss environmental group, was initially one of the strongest opponents of the hydropower project but in 2019 its members were pressured to reverse their position and support it ${ }^{8}$ while claiming all the project's environmental and socioeconomic impacts can be mitigated ${ }^{9}$. This mirrors what is happening to other nongovernmental groups and scientists who were reportedly pressured to condone or approve the project $^{3}$, or threatened with lawsuits and deportation from Indonesia ${ }^{10}$.

Indonesia is not the only nation in which 'sustainable' energy production is critically threatening biodiversity. More than 150 major hydrodams are slated for the Amazon Basin ${ }^{11}$. In Guinea, Africa, the Koukoutamba dam threatens to kill up to 1,500 critically endangered chimpanzees in a national park ${ }^{12}$. The Bumbuna dam in Sierra Leone destroyed crucial chimpanzee habitat, while the Lom Pangar dam in Cameroon destroyed habitat for both gorillas and chimpanzees ${ }^{13}$.

In our experience, a project like Batang Toru—which has spurred the most resolute scientific and popular opposition imaginable-would fail in most nations or contexts. The International Union for the Conservation of Nature has called for a moratorium on further construction until the impacts of the dam project and its associated road, earthworks and powerline infrastructure can be evaluated ${ }^{14}$. Although so far ignored, this urgent plea could help to stave off the demise of one of our closest living relatives.

William F. Laurance

Centre for Tropical Environmental and Sustainability Science, College of Science and Engineering, James Cook University, Cairns, Australia

Serge A. Wich

Liverpool John Moores University, Liverpool, UK

IUCN Species Survival Commission Primate Specialist Group

Onrizal Onrizal

University of Sumatera Utara, Medan, Indonesia

Gabriella Fredriksson

University of Edinburgh, Edinburgh, UK

University of Amsterdam, Amsterdam, Netherlands

Graham Usher

Independent environmental consultant

Truly Santika

Natural Resources Institute, University of Greenwich, UK

Dirck Byler

IUCN Species Survival Commission Primate Specialist Group

Russell Mittermeier

IUCN Species Survival Commission Primate Specialist Group

Rebecca Kormos

IUCN Species Survival Commission Primate Specialist Group 
Elizabeth A. Williamson

IUCN Red List Authority Coordinator

\author{
Erik Meijaard \\ Director of Borneo Futures, Brunei Darussalam \\ IUCN Species Survival Commission Primate Specialist Group \\ e-mail: bill.laurance@jcu.edu.au and emeijaard@gmail.com
}

\title{
References
}

$1 \quad$ Wich, S. A. et al. Cons. Sc. Prac. 1, e33 (2019).

2 Rochmyaningsih, D. Science 365, 1064-1065 (2019).

3 Jong, H. N. Available at: https://news.mongabay.com/2020/03/tapanuli-orangutanbatang-toru-nshe-iucn-ape-dam/ (2020).

4 Alliance of Leading Environmental Researchers \& Thinkers. Available at: http://alertconservation.org/indonesian-firm-using-deplorable-tactics-to-push-orangutankillerproject (2018).

5 IUCN SGA/ARRC. Batang Toru Hydropower Project. Factcheck and References on Key Issues (IUCN SGA/ARRC, USA, 2020). Available at: http://static1.1.sqspcdn.com/static/f/1200343/28292859/1588408298700/BatangToru FactcheckReport.pdf?token=lk0TiHoMOc0FBBjnJAta6Ghh3n4\%3D

6 Santosa, Y. et al. Impact of Batang Toru hydropower construction on primary forest, orangutan population and habitat, drought and flood, greenhouse gases emission and socio-economic surroundings. (The Center of Study, Advocacy and Nature Conservation, 2018).

7 Foresthints. Available at: https://www.foresthints.news/new-photos-show-tapanuliorangutans-on-the-move (2018).

8 Rochmyaningsih, D. Science, doi:10.1126/science.aaz4582 (2019).

9 Purba, J. Available at: https://rmolsumut.id/ian-singleton-dampak-plta-batangtoruterhadap-kelangsungan-hidup-orangutan-tapanuli-dapat-direstorasi/ (2020).

10 Kompasiana. Available at: https://www.kompasiana.com/maskurabdullah/5d8a1531097f361088780652/aktivisasing-menggoyang-indonesia?page $=$ all (2019).

11 Finer, M. and Jenkins, C. N. PLoS ONE 7(4):e35126.

12 Watts, J. The Guardian. Available at: https://www.theguardian.com/world/2019/feb/28/chinese-dam-project-in-guineacould-kill-up-to-1500-chimpanzees (2019).

13 Kormos, R. et al. PLOS ONE 9, e111671, doi:10.1371/journal.pone.0111671 (2014).

14 IUCN. Available at: https://www.iucn.org/news/secretariat/201904/iucn-calls-amoratorium-projects-impacting-critically-endangered-tapanuli-orangutanorangutan. (2019). 